УДК 341.63

DOI https: / / doi.org/ 10.32837 / yuv.v0i3.1943

\author{
В. Нагнибіда, \\ кандидат юридичних наук, доцент, \\ старший науковий співробітник \\ Науково-дослідного інституту приватного права і підприємництва \\ імені академіка Ф.Г. Бурчака \\ Національної академії правових наук України
}

\title{
ЗМІСТ ТА ЗНАЧЕННЯ АРБІТРАБІЛЬНОСТІ ПРЕДМЕТА СПОРУ У ПРАВОЗАСТОСОВНІЙ ДІЯЛЬНОСТІ АРБІТРАЖУ
}

\begin{abstract}
Об’єктину арбітрабільність (ratione materiae) визначають як здатність спору бути розглянутим та вирішеним у порядку арбітражу (capable of settlement by arbitration) $[1$, c. $94 ; 2$, с. $312 ; 3$, с. $91 ; 4]$. ЯK термін, так і його загальноприйняте розуміння запозичені 3 англомовної наукової літератури, що зумовлює використання транслітерованих англіцизмів «арбітрабільність» та «арбітрабільний» (поширені також скальковані російськомовні варіанти «арбітрабельність» та «арбітрабельний», пропонується використовувати поняття «арбітровний» [5], що відповідає правилам словотворення української мови, усі з яких за смисловим навантаженням $€$ тотожними згаданим вище). Семантичне значення досліджуваних категорій свідчить про ix використання для характеристики описуваного явища - предмета спору, як такого, що $€$ або не $€$ арбітрабільним. Тому при встановленні співвідношення між поняттям об'єктивної арбітрабільності та предметом спору слід виходити з того, що арбітрабільність $€$ нормативно визначеною властивістю предмета спору, індикатором належності останнього до категорії спорів, що можуть розглядатись та вирішуватись арбітражним судом у межах конкретного правопорядку.

Таким позиціям відповідає бачення арбітрабільності як правової кате-
\end{abstract}

горії suigeneris, що не кореспондує повною мірою усталеним у процесуальному праві інститутам компетенції та підвідомчості. Із цього приводу слушним є твердження Т.В. Сліпачук, яка зазначає, що арбітрабільність як термін доволі адекватно відображає специфіку підвідомчості спорів саме третейським судам, оскільки виражає встановлену державою допустимість передачі тих чи інших спорів за згодою сторін на розгляд у недержавний суд [6, с. 134]. Допустимість, на противагу обов'язковості, імперативності, вибору сторонами арбітражного порядку вирішення спору, що за своїм змістом підпадає під встановлені законом критеріі, є одним із базових проявів правової природи міжнародного комерційного арбітражу, втілюючи принципи диспозитивності арбітражного розгляду та автономії волі сторін.

3 огляду на означену важливість досліджуваної проблематики їй приділяли увагу як вітчизняні, так і зарубіжні вчені, зокрема I. Бантекас, С. Брекулакіс, М.В. Купцова, М.М. Мальський, О.С. Перепелинська, Ю.Д. Притика, А. Редферн, Т.В. Сліпачук, Т. Стіпановіч, I. Фортьє, О.М. Фролов, М. Хантер, Л. Шор та інші. При цьому значенню та порядку встановлення арбітрабільності предмета спору крізь призму механізму правозастосовної діяльності досі приділялось недостатньо уваги, що зумовило наш науковий 
інтерес та теоретико-практичне призначення цієї праці.

Таким чином, метою статті є визначення сутності об'єктивної арбітрабільності в контексті механізму правозастосування в міжнародному комерційному арбітражу, висвітлення основних критеріїв, що вказують на можливість вирішення конкретного спору або категорій спорів у порядку арбітражу, а також аналіз відповідних положень міжнародних актів та національного законодавства розвинених арбітражних юрисдикцій.

За твердженням Ю.Д. Притики, категорія арбітрабільності $€$ значно ширшою за предметну підвідомчість, охоплюючи суб'єктивну та об'єктивну складові, де лише друга стосується предмета спору. Ключовою в розумінні складності правової природи та відносності при застосуванні до конкретних правовідносин вбачається й відзначена вченим залежність арбітрабільності від факторів місця (яке право слід застосовувати до арбітрабільності предмета спору?) та часу (чи підіймається питання об'єктивної арбітрабільності до, під час або після арбітражного розгляду?) [7, с. 212 ; 8, с. 13].

Прийнятий нами в цьому дослідженні підхід до розуміння об'єктивної арбітрабільності властивий європейським правовим системам та відповідній судовій і арбітражній практиці, означаючи, за формулюванням I. Бантекаса, «дозвіл, наданий законами держави на вирішення спору в арбітражі, на противагу обов'язковому судовому вирішенню» [9, с. 193], у той час як в американській доктрині та правозастосуванні арбітрабільність додатково пов'язують із питанням наявності у складу арбітражу достатніх повноважень для вирішення питання, чи вправі арбітраж самостійно primafacie встановлювати свою компетенцію стосовно вирішення спору [10, с. 1].

Таким чином, поняття об'єктивної арбітрабільності залежно від контек- сту може відноситись як до характеристики предмета конкретного спору чи категорії спорів (тут вживається прикметник «арбітрабільний»), так i визначати допустимий предметний обсяг компетенції арбітражного суду в межах певної правової системи (чому кореспондує іменник і відповідний термін «арбітрабільність» в його предметній, об’єктивній складовій). При цьому слід враховувати, що поняття арбітрабільності своїм походженням та застосуванням завдячує арбітражній науці, засновуючись на поширених у міжнародних та національних нормативних актах описових конструкціях, хоча зустрічається й легальне використання цього терміна.

Класично питання арбітрабільності розглядається крізь призму зіткнення інтересів національного публічного порядку та потреб міжнародної спільноти щодо забезпечення функціонування міжнародного комерційного арбітражу як ефективного альтернативного способу вирішення спорів. У світлі цього об'єктивна арбітрабільність постає одним із інструментів узгодження цих інтересів, що дозволяє відмежувати категорії спорів, стосовно яких виключною юрисдикцією наділені національні суди, від тих, що можуть бути предметом арбітражного розгляду, є арбітрабільними.

Теорія арбітрабільності предмета спору є достатньо розробленою в науці та практиці міжнародного комерційного арбітражу, засновуючись на тлумаченні, та подальшому розвитку міжнародних актів, національних законодавствах i правозастосовній практиці, засадничих положень Нью-Йоркської конвенції 1958 р. [11], попри те, що сам термін у Конвенції не закріплено. Так, згідно зі ст. II(1) Конвенції кожна Договірна Держава визнає письмову угоду, за якою сторони зобов'язуються передавати в арбітраж всі або будь-які спори, що виникли або можуть виникнути між ними у зв'язку з будь-яким конкретним договірним або іншим 
правовідношенням, об’єкт якого може бути предметом арбітражного розгляду. Також відповідно до ст. V(2)(a) Нью-Йоркської конвенціï 1958 р. у визнанні та приведенні до виконання арбітражного рішення може бути відмовлено, якщо компетентна влада країни, в якій запитується визнання та приведення до виконання, з'ясує, що об’єкт спору не може бути предметом арбітражного розгляду за законами иієї країни.

Посилання на неарбітрабільність предмета спору як підставу для визнання відсутності у складі арбітражу компетенції на його вирішення та застосування відповідних механізмів судового втручання в арбітражний процес, серед іншого, доповнюється положеннями Європейської конвенції 1961 р. [12] (ст. VI (2) у контексті вирішення судом питання наявності та дійсності арбітражної угоди) та Типового закону ЮНСІТРАЛ [13] (ст. 34 (2)(b)(i) - у світлі підстав скасування судом арбітражного рішення).

Варто наголосити на відсутності на конвенційному та модельному рівнях уніфікованого визначення поняття та обсягу арбітрабільності, єдиного переліку категорій спорів, що $є$ арбітрабільними / неарбітрабільними. Містеліс Л. із цього приводу зазначає, що Типовий закон ЮНСІТРАЛ спонукає держави самостійно вирішувати питання арбітрабільності спорів, у той час як «спроби зменшити невизначеність шляхом закріплення більш детального положення стосовно арбітрабільності у Типовому законі дозволили б досягти незначних результатів» [14, с. 589]. При цьому зрозуміло, що врегулювання об'єктивної арбітрабільності на рівні національних законодавств не $є$ раз і назавжди вирішеною проблемою, піддаючись впливу різних факторів і тенденцій, відображаючи стан розвитку та правовий статус міжнародного комерційного арбітражу в певній державі.
Ураховуючи вищенаведене, важливість арбітрабільності спору як передумови арбітражного розгляду загалом та передумови здійснення правозастосовчої діяльності складом арбітражу зокрема не підлягає сумніву. Належним чином встановлена неарбітрабільність спору (як арбітражем, так і державним судом) залежно від стадії арбітражного розгляду свідчить або про припинення арбітражного процесу у зв'язку з відсутністю у складі арбітражу компетенції на вирішення спору, або про скасування чи неможливість виконання арбітражного рішення у відповідній державі. Зважаючи на це та 3 огляду на завдання складу арбітражу постановити виконуване рішення, аналіз об'єкта спору на предмет його арбітрабільності $€$ важливою передумовою арбітражного розгляду, однією із гарантій (хоч і з деякими уточненнями, про які мова піде далі) успішного визнання та приведення до виконання постановленого арбітражного рішення.

Отже, питання арбітрабільності предмета спору як передумови правозастосування в міжнародному комерційному арбітражі є багатоаспектним та потребує дослідження у взаємозв'язку таких складових елементів проблематики:1) категорій спорів, що за законодавствами окремих держав визначаються як арбітрабільні та неарбітрабільні; 2) аспектів визначення застосовного до арбітрабільності права; 3) встановлення суб'єктів, компетентних вирішувати питання арбітрабільності на різних стадіях арбітражного розгляду, при визнанні та приведенні до виконання арбітражного рішення. У межах цієї статті дослідимо перший із вказаних аспектів.

Історично та змістовно витоки віднесення спорів до арбітрабільних прослідковуються вже у самій правовій природі міжнародного комерцзійного арбітражу. Так, вихідним критерієм можна вважати так зва- 
ний «commercialtest», що полягає в аналізі природи спору як такого, що $є$ комерційним і витікає з комерційних правовідносин. Базовими тут виступають положення ст. I(3) Нью-Йоркської конвенції 1958 р., яка надає державам-підписантам право зробити застереження, що Конвенція застосовуватиметься лише до розбіжностей, які виникають із договірних чи недоговірних правовідносин, які визначаються як комерційні відповідно до національного права країни, яка зробила таке застереження; та текст примітки 2 до ст. 1(1) Типового закону ЮНСІТРАЛ, де стверджується про необхідність широкого тлумачення терміну «комерційний» 3 метою охоплення всіх відносин комерційного характеру, як договірних, так і недоговірних, та наводиться орієнтовний перелік відповідних угод. У світлі цього ми раніше стверджували, що підходи, закріплені на рівні Нью-Йоркської конвенції 1958 р. та Типового закону ЮНСІТРАЛ, сприяли формуванню в національних законодавствах розширювального та автономного тлумачення поняття «комерційний» щодо спорів, юрисдикцією на вирішення яких наділений склад арбітражу та які, відповідно, визнаються арбітрабільними.

При цьому «commercialtest» видається лише первинним, найбільш загальним критерієм арбітрабільності, що безпосередньо не спрямований на вирішення завдання встановлення компетенції складу арбітражу, окреслюючи правову природу арбітражу як способу вирішення спору та закладаючи основи нормативного регулювання його сутності і призначення. Саме тому прив'язка до комерційних спорів є орієнтовною та достатньо умовною, що й відображає рішення розробників Типового закону ЮНСІТРАЛ закріпити іï у примітці, а не в рамках окремого нормативного положення.

3 іншого боку, в деяких державах, що імплементували положення
Типового закону ЮНСІТРАЛ шляхом прийняття національних законів про міжнародний комерційний арбітраж, прослідковується використання примітки про комерційний характер спору, що може тлумачитись як опосередковане окреслення рамок об'єктивної арбітрабільності. Відповідні положення закріплені в якості дефініцій на рівні ст. 2(2)(a) Закону Республіки Молдова «Про міжнародний комерційний арбітраж» [15], ст. 3(11) Закону Литовської Республіки «Про комерційний арбітраж»у новій редакції 2012 року [16], абз. 4 ч. 1 ст. 2 Закону України «Про міжнародний комерційний арбітраж» [17].

Текстом цієї ж примітки послуговувались розробники Положення про МКАС при ТПП України (додаток № 1 до відповідного Закону) при доповненні нормативного положення ч. 2 ст. 1 Закону України «Про міжнародний комерційний арбітраж» у п. 2 Положення. 3'єднуючою конструкцією, використаною в Положенні, було обрано відсилання до «зовнішньоекономічних відносин», спори з яких можуть бути передані на вирішення MКАС при ТПП України, зміст яких розкривається через початковий описовий текст примітки 2 до ст. 1(1) Типового закону ЮНСІТРАЛ. Подібна логіка закріплена й у ч. 1 ст. 3 нової редакції Регламенту MKAС при ТПП України, проте текст примітки використовується вже для означення окремих категорій спорів, що в тому числі, але не виключно, належать до компетенції MKAC.

Мають місце й відмінні підходи до визначення поняття «комерційний» у національних арбітражних законах. До прикладу, відповідно до ст. 3(1)(7) Закону Угорщини про арбітраж термін «комерційний» охоплює всі комерційні або економічні, договірні та позадоговірні правовідносини [18].

При цьому, попри усталене розуміння, що комерційні спори загалом визнаються арбітрабільними

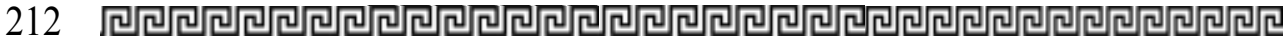


[19, с. 4], проблеми, пов'язані з особливостями розгляду та вирішення окремих категорій спорів, найчастіше пов'язаних із конкурентним (антимонопольним) законодавством, корпоративним правом, банкрутством, правом інтелектуальної власності, трудовими договорами [20, с. 104] тощо, потребують більш конкретних та деталізованих механізмів визначення обсягу об'єктивної арбітрабільності. За відсутності єдиних унормованихна міжнародному рівні підходів стосовно врегулювання цих питань, що буде проілюстровано далі, більшість правопорядків тяжіють до вирішення проблеми арбітрабільності шляхом поєднання загальних критеріїв арбітрабільності спорів, окрім або поза застосуванням «комерційного тесту», та закріплення положень, що безпосередньо стосуються виключень стосовно допустимості розгляду тих чи інших спорів складом арбітражу. Тому встановлення комерційної природи спору як передумови правозастосування в міжнародному комерційному арбітражі недостатньо не лише 3 огляду на здебільшого орієнтовний та описовий характер цієї конструкції, але й враховуючи складність віднесення окремих спорів до арбітрабільних згідно 3 нормами права відповідної держави та сформованої правозастосовної практики.

Судовий кодекс Бельгіі, нова редакція глави 6 «Арбітраж» якого була набрала чинності 2013 року, у ст. 1676(1) [21] закріплює, що будьякі майнові вимоги можуть розглядатись в арбітражі. Немайнові вимоги, щодо яких може бути укладено мирову угоду, також можуть бути передані до арбітражу. Подібні положення знаходимо у ст. 177(1) Федерального закону Швейцарії про міжнародне приватне право («Предметом арбітражного розгляду може бути будь-який спір майнового харакmеру») [22], ст. 1030(1) Арбітражного закону Німеччини (книга десята ЦПК ФРН) («Будь-яка вимога май- нового характеру (за дослівного перекладу - «пов'язана з економічним інтересом»- В.Н.) може бути предметом арбітражної угоди. Арбітражна угода стосовно вимог, що не мають майнового характеру є чинною в тій мірі, в якій сторони мають право укласти мирову угоду з питань, що є предметом спору») [23], ст. 1157 Цивільного процесуального кодексу Польщі ( ЯЯжщо інше не встановлено спеціальним актом, сторони мають право звертатись до арбітражу зі спорами стосовно прав власності та немайнових прав, що можуть бути предметом судового розгляду, за виключенням справ про стягнення аліментів») [24]. Ці ж принципи закладено й у $§ 718(1)$ Цивільного процесуального кодексу Естонії («Предметом арбітражної угоди може бути майнова вимога. Арбітражна угода, що стосується немайнової вимоги $\epsilon$ чинною лище якщо сторони мають право укласти мирову угоду стосовно об'єкта спору») [25], хоча питання арбітрабільності вирішуються тут крізь призму чинності арбітражної угоди.

Ст. 1020 (1) ЦПК Нідерландів [26] містить лише вказівку на право сторін передати в арбітраж спір, що виник або може виникнути між ними в майбутньому, що заснований на визначеному правовідношенні, незалежно від того, чи є такий спір договірним за своєю природою. ЦПК Італії у ст. 806(1) [27] передбачає право сторін на передачу спору на вирішення в арбітраж, за виключенням спорів, що стосуються питань цивільної правосуб'єктності (особистого статусу) і розлучення, а також інших спорів, що не можуть бути предметом мирової угоди. Закон Швеції про арбітраж у ст. 1 керівним принципом для можливості передачі спору на розгляд і вирішення в порядку арбітражу визначає допустимість укладення між сторонами мирової угоди стосовно предмета спору, додаючи, що арбітри 
можуть вирішувати спори, пов'язані iз цивільно-правовими наслідками застосування приписів конкурентного права. Можливість укладення сторонами мирової угоди відносно спорів, що визнаються таким чином арбітрабільними, визначено й у ст. 1(1) Закону Ісландії про договірний арбітраж [28].

Отже, до додаткових критеріїв (поруч 3 комерційною природою спору), що вказують на арбітрабільність предмета спору за законодавствами згаданих держав, можливо включити майновий (економічний) характер вимоги, поширення на відповідні спори юрисдикції судів, можливість укладення сторонами мирової угоди стосовно вимог немайнового характеру, чим забезпечується як дотримання загальних вимог процесуального законодавства, так i захищаються правовідносини, що стосуються особливо чутливих «приватних» інтересів (розлучення, відносини опіки та піклування тощо) [29, с. 37], захист яких є складовою частиною публічного порядку держави. Натомість не має визначального значення договірна чи недоговірна природа правовідносин, iз приводу яких виник або може в подальшому виникнути спір.

Утім, можливо зробити висновок, що наведені критерії не $є$ універсальними. Не повинні вони бути й вичерпними. Оскільки головним $€$ закріплення гнучкої дефінітивної формули, конкретний обсяг якої визначатиметься реаліями комерційного обороту, тоді як дотримання вимог національного публічного порядку в частині закріплення меж арбітрабільності забезпечуватиметься формуванням виключень із загального правила. У зв'язку із цим питання визначення категорій спорів, що є неарбітрабільними, постає складним і цікавим та може бути предметом наукових досліджень в обраній нами сфері юридичного знання.
У статті досліджуються питання змісту правової категорії арбітрабільності предмета cnopy під час розгляду $i$ вирішення спорів у порядку міжнародного комериійного арбітражу. Автор вказуе на доктринальне походження терміна арбітрабільності, що із часом поширився й y нормативній площині в межах законодавства окремих юрисдикцій. Наголошується, що об'єктивна арбітрабільність залежно від контексту може відноситись як до характеристики предмета конкретного cnopy чи категоріï спорів, так і визначати допустимий предметний обсяг компетениіi арбітражного суду в межах певної правової системи, чому й кореспондуе відповідний термін «арбітрабільність» в його предметній, об'єктивній складовій.

Вивчається значення арбітрабільності спору як передумови арбітражного розгляду загалом та передумови здійснення правозастосовчої діяльності складом арбітражу зокрема. Так, автор стверджує, шо належним чином встановлена неарбітрабільність спору (як арбітражем, так $i$ державним судом) залежно від стадіï арбітражного розгляду свідчить або про припинення арбітражного процесу у зв'язку з відсутністю у складі арбітражу компетениіï на вирішення спору, або про скасування чи неможливість виконання арбітражного рішення у відповідній державі. Зважаючи на ие та з огляду на завдання складу арбітражу постановити виконуване рішення, аналіз об'єкта спору на предмет його арбітрабільності є ванливою передумовою арбітражного розгляду, однією із гарантіü успішного визнання та приведення до виконання постановленого арбітражного рішення.

Резюмується, що питання арбітрабільності предмета спору

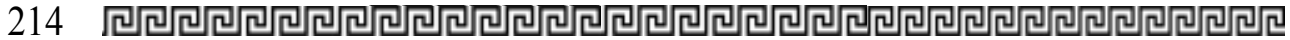


як передумови правозастосування в міннародному комериійному арбітражі є багатоаспектним та потребує дослідження у взаємозв'язку таких складових елементів проблематики: 1) категорій спорів, що за законодавствами окремих держав визначаються як арбітрабільні та неарбітрабільні; 2) аспектів визначення застосовного до арбітрабільності права; 3) встановлення суб'єктів, компетентних вирішувати питання арбітрабільності на різних стадіях арбітражного розгляду, при визнанні та приведенні до виконання арбітражного рішення.

Ключові слова: міжнародний комерційний арбітраж, арбітрабільність, предмет спору, арбітражний розгляд, автономія волі сторін.

Nahnybida V. Content and significance of arbitrability of the subject of the dispute in the law enforcement activity of the arbitration tribunal

The article examines the content of the legal category of arbitrability of the subject matter of the dispute in the resolution of disputes in international commercial arbitration. The author points to the doctrinal origin of the term of arbitrability, which over time has spread in the regulatory sphere within the legislation of individual jurisdictions. It is emphasized that objective arbitrability, depending on the context, can refer both to the characteristics of the subject of a particular dispute or category of disputes, and determine the allowable substantive scope of the arbitral tribunal competence within a particular legal system, which corresponds to the term "arbitrability" in its subject mattercomponent.

The importance of arbitrability of the dispute as a prerequisite for arbitration in general and a prerequisite for law enforcement activities of the arbitrationtribunal in particular is studied. Thus, the author argues that a properly established non-arbitrability of the dispute (both by arbitrators and the state court) depending on the stage of arbitration proceedings indicates either the termination of the arbitration process due to lack of jurisdiction to resolve the dispute, or cancellation or impossibility of enforcement of the arbitral award in the respective state. In view of this and in view of the task of the arbitral tribunal to determine the enforceable decision, the analysis of the object of the dispute for its arbitrability is an important prerequisite for arbitration, one of the guarantees of successful recognition and enforcement of the arbitral award.

It is summarized that the issue of arbitrability of the subject matter of the dispute as a prerequisite for law enforcement in international commercial arbitration is multifaceted and requires research into the relationship of the following components: 1) categories of disputes that are defined as arbitrable and non-arbitrable; 2) aspects of determining the law applicable to arbitrability; 3) the establishment of entities competent to resolve the issue of arbitrability at different stages of arbitration, during the recognition and enforcement of the arbitral award.

Key words: international commercial arbitration, arbitrability, subject matter, arbitration process, party autonomy.

\section{Лiтература}

1. Redfern A., Hunter M., Blackaby $N$. Partasides C. Redfern and Hunter on International Arbitration. 5-th ed. Oxford University Press, 2009. 776 p.

2. Fouchard, Gaillard, Goldman on International Commercial Arbitration / Philippe Fouchard, Berthold Goldman, Emmanuel Gaillard, John Savage. Kluwer Law International, 1999. 1280 p. 
3. Di Pietro D., Platte M. Enforcement of International Arbitration Awards. The New York Convention of 1958. Cameron May Ltd., 2001. 282 p.

4. ICCA's Guide to The Interpretation of the 1958 New York Convention: A Handbook for Judges. URL: https: / / www arbitrationicca.org / media / 12 / 78086121165466 / judges_guide_nyc_english_2018_reprint. $p d f$

5. Перепелинська О. Які спори (не) можна передаватинавирішенняміжнародного арбітражу за законодавством Українu? URL: https://www.integrites.com/ uk/publications / yaki-spori-ne-mozhnaperedavati-na-virishennya-mizhnarodnogoarbitrazhu-za-zakonodavstvomukrainil.

6. Слипачук T.В. Арбитрабильность международных коммерческих споров в Украине. Вестник международного коммерческого арбитража. 2010. № 1. C. 133-142.

7. Притька Ю. Формирование доктринь арбитрабильности в украинском праве. Международный коммерческий арбитраж: вызовы современности. Сборник статей и докладов. $K$ 25-летию деятельности МКАС при ТПП Украинь и развития международного коммерческого арбитража в Украине. Киев : 2017. C. 205-214

8. Притика Ю.Д., Амборський А.В. Щодо поняття і складових арбітрабельності: теоретичний аналіз. Науковий вісник Херсонського державного універcumeту. Серія Юридичні науки. 2016. Bunyck 1. Tом 2. C. 1-13.

9. Bantekas I. The Foundations of Arbitrability in International Commercial Arbitration. Australian Year Book of International Law. 2008. Vol. 27. P. 193-223.

10. Shore L. Defining 'Arbitrability' The United States us. the rest of the world. New York Law Journal. 2009. P. 1-2.

11. Convention on the Recognition and Enforcement of Foreign Arbitral Awards (New York, 1958). United Nation Organization. URL: https: / / www.uncitral.org/ pdf/english / texts / arbitration / NY-conv/ New-York-Convention-E.pdf.

12. EuropeanConvention

International Commercial Arbitration. Geneva, 21 April 1961 Treaty Collection. United Nations Organization. URL: https: / / treaties.un.org / doc/ Treaties/1964/01/19640107\%20
02-01\%20AM /Ch_XXII_02p.pdf

13. UNCITRAL Model Law on International Commercial Arbitration (with amendments as adopted in 2006). The United Nations Commission on International Trade Law. URL: https:// www.uncitral.org / pdf/english/texts / arbitration/ml-arb/07-86998_Ebook.pdf.

14. Concise International Arbitration / ed. by Loukas A. Mistelis. New York: Kluwer Law International, 2010. 1115 p.

15. Закон Республики Молдова «O международном коммерческом арбитраже» от 22 февраля 2008 года № 24-XVI. URL: http: / / base.spinform.ru/ show_doc.fwx?rgn=23314.

16. The Republic of Lithuania Law on Commercial Arbitration 2 April 1996 No I-1274. URL: https:// www.international-arbitration-attorney. com / wp-content / uploads / 2013/07 / Lithuania-Arbitration-Law.pdf.

17. Про міжнародний комериійний арбітраж: Закон України від 24.02.1994 p. № 4002-ХII / Верховна Рада України. Законодавство України. URL: https:// zakon.rada.gov.ua/laws / show / 4002-12.

18. Hungary Act LX of 2017 on arbitration (as in force on 2 January 2018). URL: http: / / www.ilo.org / dyn/natlex/ docs / ELECTRONIC / 106843/13125 7 / F-266585574 / J2017T0060P_20180102_ FIN.pdf.

19. Choice of Venue in International Arbitration / edited by Michael Ostrove, Claudia Salomon, and Bette Shifman. Oxford University Press, 2014. 656 p.

20. The Freshfields Guide to Arbitration Clauses in International Contracts, Third / Jan Paulsson, Nigel Rawding, et al. (eds). Kluwer Law International, 2010. 192 p.

21. Belgian Judicial Code, in force as from September 1, 2013 (as amended on December 25, 2016). URL : http:// wrw.cepani.be/en/arbitration/belgian-judicial-code-provisions.

22. Swiss Federal Statute on Private International Law of December 18, 1987. URL: https: / / www.swissarbitration.org / files / 34 / Swiss\% 20International\% 20 Arbitration\% 20Law/IPRG_english.pdf.

23. Arbitral Proceedings Reform Act (German Arbitration Act), entered into force on January 1998. URL: https:// sccinstitute.com/media/29988/germanarbitration-act.pdf.

24. Polish Civil Procedure Code Act of 17 November 1964. URL: 
http: / / arbitration-poland.com/legalacts/139,polish_civil_procedure_code_-act_of_17_november_1964_valid_ from_10_ianuary_2017_.html.

25. Estonia Code of Civil Procedure, entry into force 01.01.2006. URL: https: / / www.riigitea taja.ee/en/eli / 5131 22013001 / consolide.

26. Dutch Code of Civil Procedure Effective 1 October 2019. Book 4. Arbitration. URL: http://www.dutchcivillaw.com/ civilprocedureleg.htm.
27. Italian Code of Civil Procedure as of 28 October 1940. URL: http:// wrw.ipsoa.it/codici/cpc/ $14 /$ t8.

28. Iceland Act No. 53.1989, on Contractual Arbitration. URL: http:// www.newyorkconvention.org / national+ arbitration+law+-+iceland.

29. Baron Patrick M., Liniger Stefan A Second Look at Arbitrability. Approaches to Arbitration in the United States, Switzerland and Germany. Arbitration International. 2003. Vol. 19. No. 1. P. 27-54. 